\title{
PERTUMBUHAN PLANLET HASIL SILANGAN Phalaenopsis PADA MEDIA ORGANIK KOMPLEKS
}

\section{PLANTLETS GROWTH OF Phalaenopsis CROSSES RESULT ON ORGANIC COMPLEX MEDIA}

\author{
Sri Rianawati*1 \\ ${ }^{1}$ Balai Penelitian Tanaman Hias, Jl. Raya Ciherang-Pacet, Cianjur 43253 \\ *Korespondensi: sririanawati22@gmail.com
}

\begin{abstract}
ABSTRAK
Penelitian mengenai penggunaan tambahan ekstrak organik sangat diperlukan untuk mendukung usahatani skala menengah ke bawah dengan adanya paket teknologi murah. Penelitian ini bertujuan untuk melihat respon pertumbuhan planlet anggrek Phalaenopsis menggunakan media dasar pupuk Growmore sebanyak 2g/l yang diberi tambahan masing-masing ekstrak organik kompleks yaitu ekstrak kentang (PE), ekstrak tomat (TE), ekstrak jagung manis (CE) dan ekstrak taoge (SE) masing-masing dengan konsentrasi $75 \mathrm{~g} / \mathrm{l}$, dibandingkan dengan media Vacin \& Went (VW) tanpa zat pengatur tumbuh $\left(\mathrm{V}_{0}\right)$ dan VW yang diberi tambahan pepton $1 \mathrm{~g} / \mathrm{L}$ $\left(\mathrm{P}_{1}\right)$ digunakan untuk menguji pertumbuhan embrio biji Phalaenopsis silangan 529, 508, dan 655. Hasil penelitian ini menunjukkan bahwa dari enam macam media, $\mathrm{P}_{1}$ merupakan media yang paling sesuai untuk pembesaran planlet Phalaenopsis, kemudian $\mathrm{V}_{0}$ hampir menyamai pengaruhnya seperti $\mathrm{P}_{1}$. Ekstrak tambahan terbaik adalah ekstrak kentang (PE) sebanyak $75 \mathrm{~g} / \mathrm{L}$, selanjutnya diikuti ekstrak tomat (TE), kecambah (SE) dan terkecil pengaruhnya adalah ekstrak jagung manis. Jenis silangan tidak berpengaruh terhadap pertumbuhan planlet pada media yang dikombinasi dengan ekstrak organik. Rekomendasi penggunaan media yang dapat diusulkan sebagai media murah berdasarkan respon planlet Phalaenopsis pada ekstrak organik yang ditambahkan pada media dasar pupuk daun adalah ekstrak kentang.
\end{abstract}

Kata Kunci: Pertumbuhan planlet, ekstrak organik, pupuk daun, Phalaenopsis

\begin{abstract}
A Research on the use of additional organic extracts is indispensable to support lower middle-scale farming with a cheap technology package. This research were conducted to look at the growth response of the orchid plantlets Phalaenopsis using the basic media Growmore fertilizer which is given the addition of each complex organic: potato extract (PE), tomato extract (TE), sweet corn extract (CE) and bean sprouts extract (SE) each with a concentration of $75 \mathrm{~g} / \mathrm{L}$. The four media organic were compared with the media vacin \& Went (VW) without growing regulatory substances (V0) and VW which was given additional peptone 1g/L (P1) used to test the growth of Phalaenopsis seed embryos 529, 508, and 655 populations. The results of this study showed that on six media types, P1 was the most suitable media for Phalaenopsis plantlets enlargement, then V0 almost equal its influence like P1. The best supplemental extract is potato extract (PE) as much as $75 \mathrm{~g} / \mathrm{L}$, here in after followed by tomato Extract (TE), Sprouts (SE) and smallest of its influence is sweet corn extract. The genotype does not affect the growth of plantlets in media organic extracts combine. Recommendations for the use of media that can be proposed as a cheap medium based on Phalaenopsis plantlets response on organic extracts added to the basic medium of leaf fertilizer was the potato extract.
\end{abstract}

Key words: plantlet growing, organic extract, fertilizer, Phalaenopsis 


\section{PENDAHULUAN}

Agribisnis Anggrek khususnya Phalaenopsis telah dikembangkan di Indonesia sejak beberapa dasawarsa yang lalu. Secara ekonomi, komoditas Phalenopsis memiliki potensi yang tinggi sehingga mampu menjadi sumber pendapatan petani dan bahkan menjadi sumber devisa negara. Usaha anggrek di Indonesia sebagian besar dilakukan oleh pelaku usaha berskala kecil dan pada umumnya kurang mampu dalam memproduksi bibit sendiri. Untuk membantu usahatani skala menengah ke bawah dalam memproduksi bibit diperlukan paket teknologi murah.

Perbanyakan anggrek melalui biji secara in vitro dilakukan dengan cara menumbuhkan pada media buatan secara aseptik. Beberapa media buatan untuk pertumbuhan planlet anggrek adalah media Vacin \& Went (VW), Knudson'C atau Murashige Skoog (MS) yang memiliki komposisi cukup banyak jenisnya. Kandungan ekstrak organik beberapa bahan makanan seperti kentang, jagung manis, tomat dan kecambah kacang hijau cukup lengkap, diperkirakan bisa mewakili kebutuhan nutrisi media buatan untuk kultur secara in vitro. Dari beberapa penelitian diketahui bahwa pada kentang mengandung karbohidrat, protein, mineral kalium, fosfor, magnesium juga vitamin $\mathrm{C}$, thiamin (B1), niasin (B3), piridoxin (B6), dan asam pantothenat (B5), asam folat (B9) (Islam et al, 2012; Gnasekaran et al. 2012). Pada jagung mengandung selain protein, karbohidrat, juga mengandung mineral- mineral vit C, B1, fosfor , $\mathrm{Cu}, \mathrm{Mn}, \mathrm{Mg}$ (Shah et al. 2016), sedangkan tomat, selain zat-zat tersebut diatas masih mengandung vit $\mathrm{C}$, glukose, fruktose (Sua'rez et al. 2008). Pada kecambah kacang hijau banyak mengandung berbagai asam amino (Wongsiri et al 2015). Kandungan nutrisi pada kentang, jagung manis, tomat dan taoge dapat dilihat pada tabel 1 yang diambil dari data base United States Department of Agriculture (USDA) Agricultural Research Service, National Nutrient Database for Standard Reference Legacy Release.

Penelitian mengenai penggunaan ekstrak organik sudah banyak dilakukan pada perkecambahan anggrek terutama pada Dendrobium. Ekstrak organik yang umum digunakan adalah pisang (Vyas et al. 2009; Islam et al. 2016) dan air kelapa (David et al. 2015), Namun demikian penggunaan tambahan zat organik kompleks ini masih menggunakan media dasar tertentu seperti misalnya Vacin \& Went, Knudson C atau MS. Penggunaan ekstrak onganik yang lain sangat jarang ditemukan publikasinya karena belum banyak dilakukan khususnya untuk pembesaran planlet, namun demikian ada beberapa publikasi mengenai penggunaan beberapa ekstrak organik seperti kentang dan tomat (Islam et al. 2011; Gnasekaran et al. 2012; David et al. 2015). Aktar et al. (2008) menggunakan ekstrak organik tambahan untuk menumbuhkan plb Dendrobium. Pada Phalaenopsis violacea, Gnasekaran et al. (2010) menggunakan ekstrak pepaya, tomat dan air kelapa serta pisang, tanpa tambahan zat pengatur tumbuhan. 
Berdasarkan pengetahuan mengenai kandungan nutrisi bahan makanan tersebut, pada penelitian ini diaplikasikan ekstrak organik kentang, tomat, jagung manis dan kecambah kacang hijau pada media pertumbuhan planlet Phalaenopsis.

\section{BAHAN DAN METODE}

\section{Penyiapan Bahan Tanam}

Bahan penelitian yang digunakan adalah planlet hasil silangan Phalaenopsis antara lain 508 (Phal. Taisuco Kochdian selfing), $655 \quad$ (Phal. Taisuco Kochdian/Yukimai) x Phal. Taisuco Kochdian); 529 (Phal. Brother Sara Gold x Phal. Sogo Viogold). Planlet tersebut berumur 8 minggu setelah sebar sehingga masih berupa protokorm yang baru mulai muncul calon daun.

\section{Penyiapan Media Pembesaran planlet}

Media yang digunakan adalah 6 macam media yang terdiri atas 2 macam media strandart yaitu Vacin dan Went tanpa hormon (V0) dan Vacin \& Went yang ditambah pepton 1 gram/l (P1) yang diberi gula pasir $20 \mathrm{~g} / \mathrm{L}$ dan agar 7,5 g/L, dan 4 macam media pupuk NPK daun yakni Growmore 32:10:10 yang diberi tambahan ekstrak organik kentang (PE), tomat (TE), jagung manis (CE) dan tauge (SE). Ke empat macam media organik berisi $2 \mathrm{~g} / \mathrm{l}$ pupuk Growmore NPK 32: 10; 10 yang masing masing ditambah $75 \mathrm{~g} / \mathrm{l}$ juice kentang, tomat, jagung manis dan kecambah kacang hijau/tauge, dengan cara dihaluskan dengan blender. Semua media ditambahkan 150 $\mathrm{ml} / \mathrm{l}$ air kelapa, dipadatkan dengan agar 7,5 g/l dan sumber karbon gula pasir $20 \mathrm{~g} / \mathrm{l}$, dan larutan media pH 5,2.

\section{Kondisi Kultur}

Bahan tanam berupa protokorm yang telah mulai muncul calon daun, ditanam pada keenam media pada botol jem. Inkubasi dilakukan pada ruang terang dengan suhu ruang $\quad 25 \mathrm{C} \quad$ selama 3 kali periode pengamatan denagn interval 4 minggu.

\section{Rancangan Percobaan}

Percobaan ini dilakukan pada 3 jenis populasi silangan yaitu populasi 655,508 dan 529 yang dirancang berdasarkan rancangan acak lengkap dengan tiga ulangan. Faktor pertama jenis silangan dan faktor kedua jenis media, masing-masing perlakuan terdiri dari 3 botol yang masing masing berisi 10 planlet.

Peubah yang diamati meliputi jumlah daun planlet, panjang daun, lebar daun, jumlah akar, dan diameter akar. Pengamatan dilakukan dengan interval 4 minggu sebanyak 3 kali pengamatan. Data yang diperoleh dianalisis menggunakan analisis variansi (ANOVA) dengan program SAS. 9.12. Perbedaan nilai yang diperoleh dalam perlakuan akan dianalisis lebih lanjut dengan menggunakan uji jarak berganda Duncan dengan $\alpha 5 \%$.

\section{HASIL DAN PEMBAHASAN}

Pertumbuhan planlet yang berasal dari embrio biji silangan Phalaenopsis sangat dipengaruhi oleh jenis media yang digunakan. Respon yang ditimbulkannya sangat bervariasi. Pada Tabel 1 diketahui bahwa keempat media yang diberi tambahan 
Tabel 1. Pengaruh ekstrak tomat, taoge, kentang, jagung, serta media Vacin \& Went dengan pepton (P1), dan Vacin \& Went tanpa ZPT $\left(\mathrm{V}_{0}\right)$ pada pertumbuhan planlet anggrek Phalaenopsis.

\begin{tabular}{ccccccc}
\hline Media & $\begin{array}{c}\text { Panjang } \\
\text { daun } \\
\text { (cm) }\end{array}$ & $\begin{array}{c}\text { Lebar daun } \\
\text { (cm) }\end{array}$ & $\begin{array}{c}\text { Jumlah daun Jumlah Akar } \\
\text { (cm) }\end{array}$ & $\begin{array}{c}\text { Panjang } \\
\text { Akar (cm) }\end{array}$ & $\begin{array}{c}\text { Diameter } \\
\text { Akar } \\
\text { (cm) }\end{array}$ \\
\hline $\mathrm{V}_{0}$ & $2,00 \mathrm{a}$ & $1,28 \mathrm{a}$ & $0,89 \mathrm{a}$ & $1,41 \mathrm{c}$ & $0,68 \mathrm{ab}$ & $0,19 \mathrm{abc}$ \\
$\mathrm{P} 1$ & $2,05 \mathrm{a}$ & $1,22 \mathrm{a}$ & $0,76 \mathrm{~b}$ & $1,61 \mathrm{a}$ & $0,75 \mathrm{a}$ & $0,22 \mathrm{a}$ \\
$\mathrm{TE}$ & $1,82 \mathrm{~b}$ & $0,88 \mathrm{c}$ & $0,62 \mathrm{e}$ & $1,58 \mathrm{ab}$ & $0,54 \mathrm{c}$ & $0,18 \mathrm{c}$ \\
$\mathrm{SE}$ & $1,81 \mathrm{~b}$ & $0,95 \mathrm{c}$ & $0,52 \mathrm{e}$ & $1,67 \mathrm{a}$ & $0,74 \mathrm{a}$ & $0,18 \mathrm{bc}$ \\
$\mathrm{PE}$ & $2,06 \mathrm{a}$ & $1,13 \mathrm{~b}$ & $0,66 \mathrm{c}$ & $1,40 \mathrm{bc}$ & $0,67 \mathrm{ab}$ & $0,19 \mathrm{abc}$ \\
$\mathrm{CE}$ & $1,67 \mathrm{c}$ & $0,69 \mathrm{~d}$ & $0,58 \mathrm{~d}$ & $1,34 \mathrm{c}$ & $0,61 \mathrm{bc}$ & $0,21 \mathrm{ab}$ \\
\hline
\end{tabular}

Keterangan : Angka yang diikuti oleh huruf yang sama pada kolom yang sama menunjukkan tidak berbeda nyata pada uji Duncan taraf 5\%. Media berisi ekstrak tomat (TE), ekstrak taoge (SE), ekstract kentang (PE), ekstrak jagung ( CE), Vacin \& Went dengan pepton (P1), Vacin and Went tanpa hormon (V0).

ekstrak organik yang digunakan ternyata masih belum menyamai hasilnya seperti pada media standart yaitu $\mathrm{V}_{0}$ (Vacin \& Went tanpa hormon) dan P1.

Pada media $\mathrm{V}_{0}$ ini planlet tumbuh cukup optimum baik daun maupun perakarannya (Gambar 1), meskipun bukan yang terbaik dalam penelitian ini. Dari keenam macam media yang digunakan dalam penelitian ini, media Vacin \& Went yang ditambah pepton $1 \mathrm{~g} / \mathrm{L}$ merupakan media yang paling sesuai. Pemakaian masingmasing pupuk sebanyak $2 \mathrm{~g} / \mathrm{l}$ yang ditambah ekstrak 75 g/l, memberikan pengaruh kurang efisien dibandingkan dengan media Vacin \& Went.

Di antara ekstrak tersebut, ekstrak kentang yang ditambahkan pada pupuk growmore (PE) memberikan pengaruh yang lebih baik dibandingkan dengan ekstrak yang lain. Pengaruhnya pada panjang dan lebar daun sangat jelas. Rata-rata jumlah daun pada penggunaan PE juga paling tinggi bila dibandingkan dengan penggunaan TE, SE atau CE.

Pada media PE tidak semua peubah memiliki nilai tertinggi, tetapi secara penampilan, proporsi ukuran tanaman menjadi lebih baik atau sesuai dibandingkan dengan penambahan ekstrak yang lain seperti terlihat pada Gambar 1.

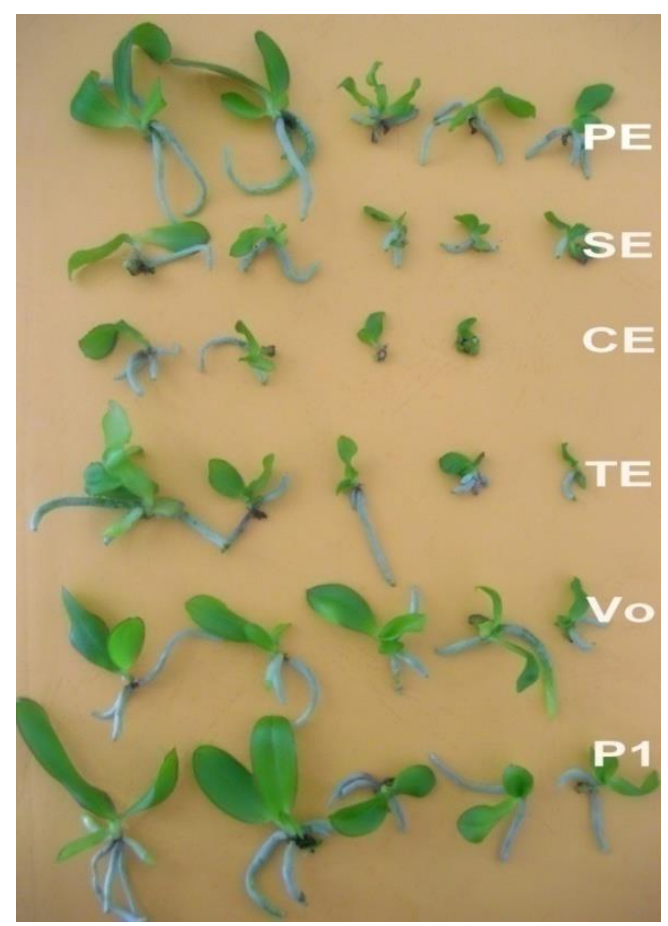

Gambar 1. Pertumbuhan planlet Phalaenopsis klon 508 pada media pupuk yang diberi tambahan ekstraks organik kompleks, PE (ekstrak kentang), SE(ekstrak taoge), TE (ekstrak tomat), CE (ekstrak jagung manis), Vo (Vacin \& Went tanpa hormon), P1(Vacin \&Went ditambah pepton). 
Dalam diagram pertumbuhan planlet (Gambar 2), pengamatan pertumbuhan planlet dengan interval 4 minggu pada pengamatan 1 (M1), 2 (M2), 3 (M3) menunjukkan bahwa rata-rata jumlah daun pada umur planlet 0-4 mengalami peningkatan 1,2 menjadi 2 daun per planlet, sedangkan umur 8 dan 12 minggu menjadi stabil. Pada panjang dan lebar daun, jumlah akar dan panjang akar meningkat setiap 4 mingguannya. Adapun diameter akar tidak cukup banyak berubah.

Penggunaan ekstrak kentang sebagai tambahan nutrisi telah diteliti oleh Ichihashi dan Islam pada tahun 1999, namun media yang digunakan adalah media NP (New Phalaenopsis). Hasil yang diperoleh pada penelitian tersebut menunjukkan bahwa pertumbuhan planlet terbaik adalah menggunakan ekstrak $50 \mathrm{ml} / \mathrm{l}$. Salah satu kelebihan utama ekstrak kentang sebagai tambahan nutrisi adalah adanya karbohidrat dan potassium yang cukup tinggi dibandingkan dengan yang lain.

Karbohidrat merupakan komponen utama yang sangat dibutuhkan tanaman sebagai sumber karbon sedangkan potassium sangat berperan dalam sintesis protein, enzim, sebagai activator enzim dan berfungsi sebagai perangsang pembuka dan penutup stomata. Aktar et al. (2008) memanfaatkan ekstrak organik tambahan pada pertumbuhan tanaman Dendrobium untuk mencapai keseimbangan nutrisi yang murah. Demikian pula penelitian yang dilakukan oleh Rahman et al (2004), pertumbuhan planlet Phalaenopsis meningkat dengan tambahan ekstrak kentang sebanyak $50 \mathrm{ml} / \mathrm{l}$ tetapi terhambat pada konsentrasi $200 \mathrm{ml} / \mathrm{l}$.

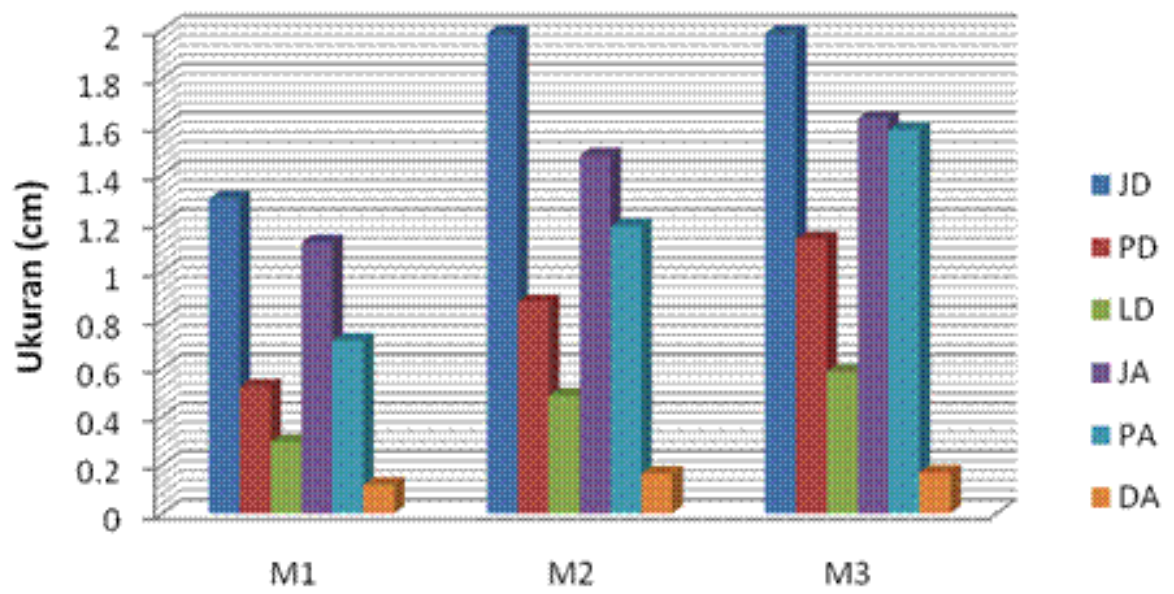

Minggu Pengamatan

Gambar 2. Diagram pertumbuhan planlet dari interval pengamatan setiap 4 MST.

Pemanfaatan ekstrak tomat juga digunakan sebagai nutrisi tambahan untuk pertumbuhan Phalaenopsis (Gnasekaran et al. 2010). Tomat paling banyak mengandung vitamin $\mathrm{A}$ dan $\mathrm{C}$ yang tidak berpengaruh pada metabolism tanaman meskipun berpengaruh terhadap pencegahan browning sebagai antioxidant. Ekstrak tomat memberikan pengaruh terbesar pada jumlah daun dan jumlah akar namun kriteria yang lain tidak optimum pertumbuhannya. 
Jagung manis banyak mengandung phosphor yang berfungsi sebagai pembentuk komponen phosphate berenergi tinggi yaitu ATP dan ADP, pembentuk asam nukleat, fosforilasi gula dan beberapa ko-enzim esensial, dan vitamin B1 yang berfungsi sebagai koenzim yang membantu siklus asam organik dari respirasi (Taji et al. 1993). Ekstrak jagung manis mempengaruhi pertumbuhan diameter akar paling besar dibandingkan dengan yang lain, sedangkan ekstrak kecambah kacang hijau mempengaruhi pertumbuhan jumlah dan panjang akar saja namun pertumbuhan daun terhambat (Tabel 1).

Penelitian ini menunjukkan bahwa di antara ekstrak kentang tomat, kecambah kacang hijau dan jagung manis, ekstrak jagung manis memberikan pengaruh terkecil baik jumlah maupun ukuran daun serta jumlah dan panjang akar, namun diameter akar cukup besar.

Tabel 2. Kandungan nutrisi pada media Vacin \& Went dan pupuk Growmore

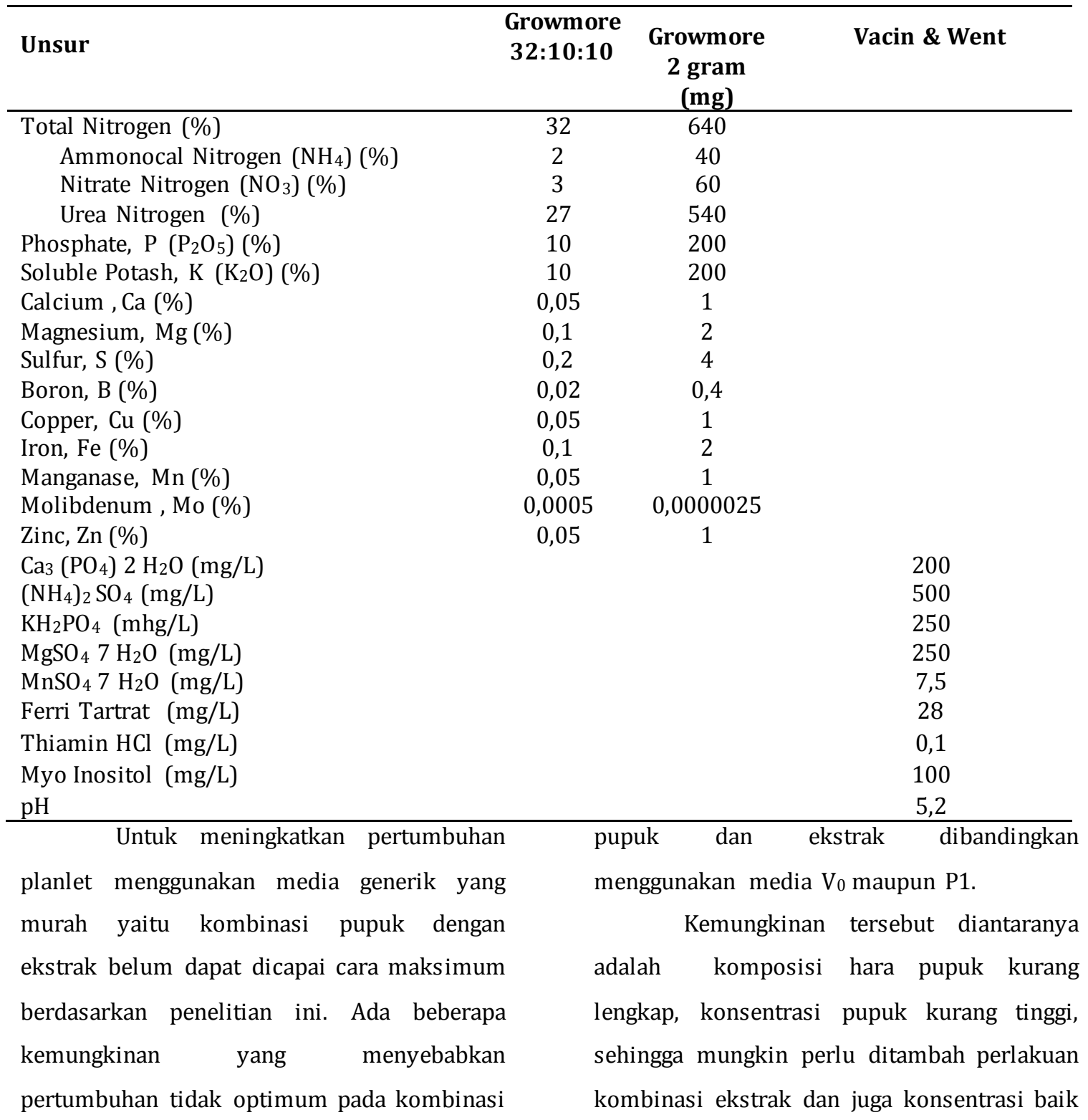


konsentrasi pupuk maupun ekstrak. karena kandungan $\mathrm{NH}_{4}$ dan $\mathrm{NO}_{3}$ yang dimiliki setiap pupuk jauh lebih rendah dari pada Vacin \& Went yang mengandung sekitar $500 \mathrm{mg}$ dan $525 \mathrm{mg}$ (Tabel 2).

Pada penelitian ini, jenis silangan yang memberikan respon terbaik adalah klon 655 (Tabel 3). Kedua jenis yang lain tidak merespon baik pada media ekstrak, tetapi tidak berbeda jauh. Jumlah daun rata-rata berkisar antara 1,84 - 1,94; panjang daun rata-rata mencapai $0,97 \mathrm{~cm}-1,11 \mathrm{~cm}$ demikian pula lebar daun, jumlah akar, panjang akar dan diameter akar rata-rata berturut-turut adalah $0,63-0,73 \mathrm{~cm} ; 1,39-$ 1,57; 0,63 - 0,7 cm dan 0,19-0,2 cm.

Tabel 3. Pengaruh genotip pada pertumbuhan planlet yang ditumbuhkan pada ekstrak organik kompleks.

\begin{tabular}{ccccccc}
\hline Genotip & $\begin{array}{c}\text { Panjang daun } \\
\text { (cm) }\end{array}$ & $\begin{array}{c}\text { Lebar } \\
\text { daun } \\
\text { (cm) }\end{array}$ & $\begin{array}{c}\text { Jumlah } \\
\text { daun } \\
\text { (cm) }\end{array}$ & $\begin{array}{c}\text { Jumlah } \\
\text { Akar }\end{array}$ & $\begin{array}{c}\text { Panjang } \\
\text { Akar (cm) }\end{array}$ & $\begin{array}{c}\text { Diameter } \\
\text { Akar (cm) }\end{array}$ \\
\hline 655 & $1,92 \mathrm{ab}$ & $1,10 \mathrm{a}$ & $0,73 \mathrm{a}$ & $1,56 \mathrm{a}$ & $0,70 \mathrm{a}$ & $0,20 \mathrm{a}$ \\
508 & $1,84 \mathrm{~b}$ & $0,97 \mathrm{~b}$ & $0,66 \mathrm{~b}$ & $1,39 \mathrm{~b}$ & $0,63 \mathrm{~b}$ & $0,19 \mathrm{a}$ \\
529 & $1,94 \mathrm{a}$ & $1,00 \mathrm{~b}$ & $0,62 \mathrm{~b}$ & $1,57 \mathrm{a}$ & $0,67 \mathrm{ab}$ & $0,19 \mathrm{a}$ \\
\hline
\end{tabular}

Keterangan : Angka yang diikuti oleh huruf yang sama pada kolom yang sama menunjukkan tidak berbeda nyata pada Duncan taraf $5 \%$.

\section{KESIMPULAN}

Penelitian ini telah diketahui pupuk daun komersial yang dapat direkomendasikan menjadi nutrisi media buatan untuk pembesaran bibit Phalaenopsis secara in vitro yaitu Growmore sebanyak 2 g/l, ditambahkan dengan ekstrak kentang sebanyak $75 \mathrm{~g} / \mathrm{l}$.

\section{DAFTAR PUSTAKA}

Aktar, S., Nasiruddin, K.M. \& Hossain, K. (2008), Effect of different media ang organic additives interaction on in vitro regeneration of Dendrobium orchid. J Agric Rural Dev 6, pp. 69-74.

David, D., Jawan, R., Marbawi, H., Gansau, J.A. (2015). Organic additives improves the in vitro growth of native orchid Vanda helvola Blume. Not Sci Biol 7:192-197.

Gnasekaran, P., Rathinam, X., Sinniah, U.R. \& Subramaniam, S. (2010). A study on the use of organic additives on the protocorm-like bodies (Plbs) growth of Phalaenopsis violacea orchid. J Phytology vol.2, no. 1, pp. 029-033. Gnasekaran, P., Poobathy, R., Mahmood, M., Samian, M.R. \& Subramaniam, S. (2012). Effects of complex organic additives on improving the growth of PLBs of Vanda Kasem's Delight. Aust J Crop Sci 6:1245-1248.

Ichihashi, S. \& Islam, M.O. (1999), Effects of complex organic additives on callus growth in three orchid genera, Phalaenopsis, Doritaenopsis and Neofinetia. J. Jpn. Soc. Hort. Sci, 68, pp. 269-274.

Islam, M.O., Rahman, A.R.M., Matsui, S.A. \& Prodan, K.M.A. (2003), Effects of complex organic extracts on callus growth and PLB regeneration through embriogenesis in the Doritaenopsis orchids. JARQ. vol. 37, no. 4.

Islam, M.O., Islam, M.S. \& Saleh, M.A. (2016) Effect of banana extract on growth and development of protocorm like bodies in Dendrobium sp. orchid. Agriculturists 13:101.

Islam, M., Akter, M., \& Prodhan, A. (2012) Effect of potato extract on in vitro seed germination and seedling 
growth of local Vanda roxburgii orchid. J Bangladesh Agric Univ 9:211-215

Kongbangkerd, A., Watthana, S.\& Srimuang, K.O. (2016). Influence of organic supplements on growth and development of in vitro shoots of Bulbophyllum dhaninivatii Seidenf. Appl Mech Mater 855:42-46

Kaplan, M., Ulger, S., Kokten, K., Uzun, S., Oral, E.V., Ozaktan, H., Temizgul, R. \& Kale, H. (2018). Nutritional composition of potato (Solanum tuberosum L.) Haulms . Progress in Nutrition 2018; Vol. 20, Supplement 1: 90-95 DOI: 10.23751/pn.v20i1-S.5541

Rahman, A.R.M., O. Islam, A.K.A. Prodhan, S. Ichihashi. (2004). Effects of complex organic extracts on planlet regeneration from PLBs and planlet growth in the Doritaenopsis orchid. JARQ. 38 (1).

Shah, T.R., Prasad, K. \& Kumar, P. (2016). Maize-a potential source of human nutrition and health: A review. Food Science and Technology. Rouf shah et al., Cogent Food \& Agriculture (2016) 2: 1166995 .

Suarez, M.H., Rodri ' guez, E.M., Rodri ' guez, C. D. \& Romero. (2008). Chemical composition of tomato (lycopersicon esculentum) from Tenerife, The Canary Islands. Food Chemistry 106 1046-1056.

Ullah, I., Ali, M., \& Farooqi, A. (2010). Chemical and Nutritional Properties of some Maze (Zea mays L) Varieties Grown in NWFP, Pakistan. Pakistan Jouernal of Nutrition 9 (11) : 11131117.

Vyas, S., Guha, S., Bhattacharya, M., \& Rao. I.U. (2009). Rapid regeneration of plants of Dendrobium lituiflorum Lindl. (Orchidaceae) by using banana extract. Sci Hortic. 121:32-37.

Wongsiri, S., Ohshima, T. \& Duangmal, K. (2015). Chemical composition, amino acid profile and antioxidant activities of germined Mung beans ( Vigna radiata). Journal of Food Processing and Preservation. ISSN 1745-4549. $2015: 1-9$ 